\title{
Penicillin Antibodies and Immunoglobulin Production in Newborn Infants: Studies with Chemically Modified Bacteriophage
}

\author{
Stanley Levin ${ }^{[28]}$, Yehudit Altman, Erga Nir, Esther Hurwitz, and Mrahael Sela \\ Pediatric Research Department, Kaplan Hospital, and Department of Chemical Immunology, Weizman Institute of Science, Rehovot, Israel
}

\section{Extract}

With the use of the highly sensitive technique of inactivation by antibody of growth of bacteriophage to which a hapten penicillin is chemically coupled, we found antipenicillin antibodies (APA) in the sera of all 25 mothers examined and their 27 newborn infants. Precise quantitation of antibodies was not performed in this study, but with the use of optimum dilution of the sera for antibody detection as the indicator, the efficiency, (i.e., a function depending both on amount and on affinity) of antibodies in the sera of the mothers was higher by a factor of 5-10 when compared with the sera of the neonates. The immunoglobulin classes of APA were determined by both the direct method after removal of a single immunoglobulin class by immunoadsorption on a Sepharose-antiimmunoglobulin column, and by indirect methods such as destruction of heat-labile immunoglobulin (immunoglobulin $\mathrm{E}$ is heat labile), and breakdown of macroglobulin (IgM) with 2-mercaptoethanol (2-ME). There was good correlation between the results by both methods, although occasionally some discrepancies were found. Most sera had APA of human immunoglobulins G, M, A, and $\mathrm{E}$ (IgG, IgM, IgA, and $\operatorname{IgE}$ ) classes, but none of the sera of seven mothers and five infants contained IgD APA. More infants than mothers had a high proportion of IgM APA, whereas there were no significant differences between the two groups with regard to $\operatorname{Ig} G$, IgA, and $\operatorname{IgE}$ APA. In premature infants, all four immunoglobulin classes of APA were found, the youngest infant examined being 6 months gestational age. The proportion of each APA immunoglobulin class in paired mother-infant sera was approximately similar in most cases. However, several pairs were found to have marked discrepancies in the proportion of a specific immunoglobulin class. In three pairs, IgA antibodies were present in mothers' sera diluted 1/500-1/1,000 but not in the infants' sera diluted $1 / 50-1 / 100$ when other immunoglobulin classes of APA were present. In several pairs, the mother had no $\operatorname{IgE} \mathrm{APA}$, whereas it was present in the infant, and, conversely, some mothers had IgE APA, whereas their infants had none. No such remarkable discrepancies were found in the $\operatorname{Ig} G$ and $\operatorname{IgM}$ classes of APA. In the two sets of twins, marked differences were found in each infant pair in the proportion of immunoglobulin class APA. These results indicate that the fetus is able to synthesize IgE antibodies, and are highly suggestive of independent synthesis of $\operatorname{IgA}, \operatorname{IgM}$, and IgG antibodies in mother and fetus. These results also suggest that synthesis of the various immunoglobulins by the fetus occurs as early as 6 months gestational age, if not earlier, and that $\operatorname{IgE}$ and $\operatorname{IgA}$ probably do not pass through the placenta consistently. The presence of antipenicillin antibodies in infants whose 
mothers had no history of receiving penicillin or its derivatives during pregnancy leads one to speculate that penicillin may be a pollutant of the food we eat and drink. However, the possibility that antibodies cross-reacting with penicillin are present in fetuses must be taken into consideration, particularly as our studies have shown that all neonates have antibodies of various immunoglobulin classes with specificity directed towards the dinitrophenyl hapten.

\section{Speculation}

Evidence that the immune system of the human fetus is competent and responds to antigenic stimulation in utero indicates that possibilities exist to immunize infants prenatally in order to supply them with adequate and specific active antibodies at birth. The presence of antibodies to penicillin in the sera of all newborn infants studied indicates either that penicillin is a universally present antigen, possibly as a pollutant passing from mother to fetus, or that cross-reacting antibodies to penicillin exist in the fetus.

\section{Introduction}

It has been well established that both the cellular and immune mechanisms of the infant develop during intrauterine life [6], so that at birth the average normal infant is adequately prepared for the massive immunologic stimulation to which it is exposed during the first days of extrauterine life.

Much interest has been evinced concerning the question of intrauterine production of immunoglobulins. Studies in the fetus and neonate have shown that active production of antibodies of the IgM class is commonly found, and occasionally those of the IgA and IgG classes. With the use of a highly sensitive technique for the detection of antibodies, in which specific antipenicillin antibodies (APA) will inactivate bacteriophage to which penicillin is coupled [9], we have shown in preliminary studies [11] that the fetus is also able to synthesize $\mathrm{IgE}$.

The present study extends this work and examines the ability of premature and full term neonates to produce antibodies of the various immunoglobulin classes to penicillin, although there is no evidence that any of the mothers had received penicillin during pregnancy.

\section{Materials and Methods}

Cord blood was obtained at birth from 27 premature and full term infants including two sets of twins, and at the same time from their 25 mothers. In some cases blood was collected on the 2 nd to 4 th day of life from infants undergoing exchange transfusion for hyperbilirubinemia. No mother had received penicillin during her pregnancy nor had the neonates received it prior to blood sampling. No case of sensitivity to penicillin was known among these mothers.

\section{Phage Preparation}

Bacteriophage $\mathrm{T} 4, \quad 10^{11}$ plaque-forming units (p.f.u.) $/ \mathrm{ml} 0.1 \mathrm{~m}$ carbonate buffer, $\mathrm{pH} 9.5$, was reacted with $100 \mathrm{mg}$ penicillin $G$ and the resulting penicilloyl-T4 phage preparation was used after treatment and testing as described by Haimovich et al. [9].

\section{Bacterial Test System}

Escherichia coli B was freshly prepared and used as the medium for phage culture [1].

\section{Immunologic Reagents and Methods}

Goat antiserum monospecific to individual human immunoglobulins G, M, A, and E (IgG, IgM, IgA, and $\operatorname{IgE}$ ) was obtained from either commercial sources or prepared in our own laboratories. Antiserum to human IgD was obtained from Dr. John Robbins [25]. After tests for specificity were made antisera were coupled to Sepharose $4 \mathrm{~B}$ by accepted methods [7, 14]. These immunoadsorbants were tested in $2.0-\mathrm{ml}$ microcolumns as to their ability to specifically bind the homotypic immunoglobulin. Goat antihuman-serum was obtained from Miles-Yeda, Rehovot, and used in later tests for enhancement of antibody detection, by the "complex inactivation method."

\section{Test System}

Paired sera of mother and infant were serially diluted with $0.05 \mathrm{x}$ phosphate buffer, $\mathrm{pH}$ 6.8, and 
$0.002 \%$ gelatin. Diluted serum $(0.1 \mathrm{ml})$ was added to an equal volume of penicillin $\mathrm{T} 4$ phage, and incubated overnight at $37^{\circ}$. Five minutes before completion of incubation, $0.025 \mathrm{ml}$ goat antihuman serum diluted $1 / 100$ was added to the reaction mixture and mixed gently (complex inactivation method). At the same time, a test tube with $2.5 \mathrm{ml} 0.6 \%$ agar was readied in a water bath at $45^{\circ}$ (Bacto-agar, $6.0 \mathrm{~g}$, Bacto-tryptone, $10.0 \mathrm{~g}, \mathrm{NaCl}, 8.0 \mathrm{~g}$, Na-citrate, $2.0 \mathrm{~g}$, and glucose, 3.0 $\mathrm{g} /$ liter distilled water). Of the stock $E$. coli mixture, $0.075 \mathrm{ml}$ was added to a tube of this top agar $5 \mathrm{~min}$ before pouring into a plastic, 9-cm petri dish covered with about $25 \mathrm{ml} 1.0 \%$ bottom agar (Bacto-agar, 10.0 g; Bacto-tryptone; 13.0 g; NaCl, 6.0 g; Na-citrate, $2.0 \mathrm{~g}$, and glucose, $1.3 \mathrm{~g} /$ liter distilled water). Immediately before pouring, the top agar with the bacteria was added to the phage-serum mixture and gently mixed. The petri dishes with the reaction mixture were incubated overnight at $37^{\circ}$, after which colony counting was performed. A concentration of phage which gave about 500 colonies $/ E$. coli plate under normal control conditions was used.

In the presence of serum antibodies specific to the penicillin hapten coupled to the phage, there will be inactivation of phage which can be quantitated by counting the number of phage plaques (growing colonies) on the $E$. coli medium. The percentage of inactivation is calculated as the difference between the number of plaque-forming units in the presence of the test serum, and that of a blank control (phosphate-buffered gelatin), taken as $100 \%$. All tests were performed in duplicate.

The following tests were performed to determine the presence of antipenicillin antibodies and their immunoglobulin classes in serum. In some cases sufficient serum was not available to complete the entire battery of tests, and in others the different specific immunoadsorbents became available only as the study progressed. (1) Sera were diluted serially and titrated with pen$\mathrm{T} 4$ phage in order to determine the optimal serum dilution at which antipenicillin antibody present would give at least $40 \%$ phage inactivation. (2) Sera were heated to $56^{\circ}$ for 1 hr to eliminate heat-labile antibodies. IgE antibody has been shown to be heat labile [21]. (3) A sample of each serum was reacted with $0.1 \mathrm{M} 2-\mathrm{ME}$ at $37^{\circ}$ for $30 \mathrm{~min}$ to inactivate $\mathrm{IgM}$ antibodies. (4) Aliquots (0.1) of sera were passed through $2.0-\mathrm{ml}$ bed-volume microimmunoadsorbent columns with antisera to $\operatorname{Ig} G, \operatorname{Ig} M, \operatorname{IgA}, \operatorname{Ig} \mathrm{E}$, and $\operatorname{Ig} \mathrm{D}$, and washed through with phosphate buffer.

\section{Controls}

In all cases a specific antipenicillin antibody blocking control was performed by adding $5 \times 10^{-2} \mathrm{M}$

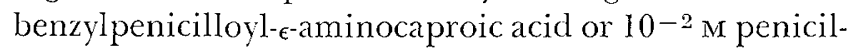
lin $G$ to the serum before incubation with the phages. A negative control with streptomycin instead of penicillin was sometimes used as was a phage control with uncoupled phage T4.

\section{Results}

By the use of the highly sensitive technique of antibody inactivation of growth of bacteriophage to which penicillin is chemically coupled, we found antipenicillin antibodies in sera of all 25 mothers tested and their 27 newborn infants. Precise quantitation of antibodies by this method was not carried out in the experiments described, but in general the efficiency (i.e., a function depending both on amount and on affinity) of antibodies in the mothers' sera was higher by a factor of $5-10$ when compared with their newborns' sera, using optimum dilution of the sera for antibody detection as the indicator. In other words, $50 \%$ inactivation of bacteriophage by a $1 / 1000$ dilution of mothers' serum corresponded to $50 \%$ inactivation by $1 / 100$ to $1 / 200$ dilution of infants' serum. As the optimum dilution for at least $40 \%$ inactivation varied in mothers and infants sera, it was necessary in comparing immunoglobulins in paired sera, to study the proportion of the total APA in each immunoglobulin class. In determining the immunoglobulin classes of APA, both the direct immunoadsorbent method, as well as indirect methods (heat lability of $\operatorname{IgE}$ antibodies and destruction of IgM antibodies by 2-ME), were used. In general there was good correlation of results by both methods, but occasionally some discrepancies were found. As no $\mathrm{IgD}$ APA were found in any of 7 mothers' and 5 infants' sera tested, no routine testing for IgD APA was made.

Table I shows the relative amounts of the various immunoglobulin classes of APA in the total group of mothers and infants. Most sera had four classes of APA (Table II). The division into three categories of minimal, moderate, and high proportion of antibody in each class is arbitrary, and has been chosen in order to separate clearly the first and last groups. It is seen that more infants than mothers had a high proportion of $\mathrm{IgM}$ antibodies, whereas there were no significant differences between the two groups with regard to $\operatorname{IgG}$, $\operatorname{Ig} \mathrm{A}$, and $\operatorname{Ig} \mathrm{E}$ antibodies. The youngest premature infant examined was of 6 months gestational age, and as can be seen from Table II, APA were present in all 
Table I. Antipenicillin antibodies in mothers and newborn infants (proportion of antibodies in each immunoglobulin class)

\begin{tabular}{|c|c|c|c|c|c|c|c|c|}
\hline \multirow[b]{2}{*}{ Immunoglobulin $(\mathrm{Ig})$ class } & \multicolumn{4}{|c|}{ Proportion of antibodies ${ }^{1}$ in mothers' sera $(n=25)$} & \multicolumn{4}{|c|}{ Proportion of antibodies ${ }^{1}$ in infants' sera $(n=27)$} \\
\hline & $\begin{array}{l}\text { None- } \\
\text { minimal } \\
(<10 \%)\end{array}$ & $\begin{array}{l}\text { Moderate } \\
\text { proportion } \\
(10-40 \%)\end{array}$ & $\begin{array}{c}\text { High } \\
\text { proportion } \\
(>40 \%)\end{array}$ & $\begin{array}{l}\text { Total } \\
\text { tested }\end{array}$ & $\begin{array}{l}\text { None- } \\
\text { minimal } \\
(<10 \%)\end{array}$ & $\begin{array}{c}\text { Moderate } \\
\text { proportion } \\
(\mathbf{1 0 - 4 0 \% )}\end{array}$ & $\begin{array}{c}\text { High } \\
\text { proportion } \\
(>40 \%)\end{array}$ & $\begin{array}{l}\text { Total } \\
\text { tested }\end{array}$ \\
\hline $\operatorname{IgA}$ & 3 & 7 & 2 & 12 & 5 & 12 & 1 & 18 \\
\hline $\operatorname{IgM}$ & 6 & 14 & 2 & 22 & 2 & 15 & 7 & 24 \\
\hline $\mathrm{IgE}$ & 5 & 18 & 1 & 24 & 6 & 17 & 3 & 26 \\
\hline 2-Mercaptoethanol sensitive & 6 & 15 & 0 & 21 & 4 & 13 & 9 & 26 \\
\hline
\end{tabular}

${ }^{1}$ Amount of inactivation of penicillin phage $T_{4}$ by serum after immunoadsorbtion or treatment.

Table II. Immunoglobulin class of antipenicillin antibodies in premature and full term infants $(n=27)$

\begin{tabular}{|c|c|c|c|c|c|c|c|c|}
\hline \multirow[b]{2}{*}{ Gestational age } & \multirow[b]{2}{*}{ Case } & \multirow[b]{2}{*}{ Serum dilution } & \multicolumn{6}{|c|}{ Proportion of antibodies in each immunoglobulin class ${ }^{2}$} \\
\hline & & & $\operatorname{IgG}$ & $\operatorname{IgA}$ & $\operatorname{IgM}$ & $\operatorname{IgE}$ & Heat labile & $\begin{array}{c}\text { 2-Mercaptoethanol } \\
\text { sensitive }\end{array}$ \\
\hline \multirow[t]{2}{*}{7 Months } & 1 & $1 / 3^{2}$ & ND & $\mathrm{ND}$ & $\mathrm{ND}$ & ++ & ++ & $+t$ \\
\hline & 2 & $1 / 3^{2}$ & $\mathrm{ND}$ & ND & ND & ++ & + & ND \\
\hline \multirow[t]{6}{*}{8 Months } & 1 & $1 / 6^{2}$ & +++ & ND & ++ & ++ & ++ & +++ \\
\hline & 2 & $1 / 3^{2}$ & ND & ND & +++ & +++ & +++ & +++ \\
\hline & 3 & $1 / 50$ & + & + & + & + & + & + \\
\hline & 4 & $1 / 50$ & ++ & + & +++ & ++ & ++ & +++ \\
\hline & 5 & $1 / 50$ & $+t+$ & +++ & ++ & ++ & ++ & ++ \\
\hline & 6 & $1 / 50$ & ++ & ++ & $+t$ & ND & ++ & ++ \\
\hline 9 Months & 1 & $1 / 50$ & ++ & ++ & ++ & ++ & + & $+t$ \\
\hline \multirow[t]{15}{*}{ Full term } & 1 & $1 / 20^{2}$ & ND & $\mathrm{ND}$ & +++ & ++ & ++ & ++ \\
\hline & 2 & $1 / 6^{2}$ & ND & ND & +++ & 0 & 0 & + \\
\hline & 3 & $1 / 10^{2}$ & $\mathrm{ND}$ & ND & +++ & ++ & ++ & +++ \\
\hline & 4 & $1 / 10^{2}$ & ND & ND & +++ & +++ & ++ & +++ \\
\hline & 5 & $1 / 10^{2}$ & $+t$ & ++ & ++ & $+t$ & $+t$ & ++ \\
\hline & 6 & $1 / 100$ & ++ & ++ & ++ & + & ++ & ++ \\
\hline & 7 & $1 / 100$ & +++ & 0 & ++ & + & ++ & 0 \\
\hline & 8 & $1 / 100$ & +++ & ++ & ++ & $+t$ & ++ & ++ \\
\hline & 9 & $1 / 100$ & ++ & ++ & $+t$ & 0 & 0 & +++ \\
\hline & 10 & $1 / 200$ & ++ & ++ & ++ & $+t$ & ++ & ++ \\
\hline & 11 & $1 / 50$ & $++t$ & $+t$ & ++ & $+t$ & ++ & ++ \\
\hline & 12 & $1 / 50$ & $++t$ & + & ++ & $t+$ & ++ & ++ \\
\hline & 13 & $1 / 50$ & ++ & ++ & 0 & ++ & ++ & 0 \\
\hline & 14 & $1 / 50$ & ++ & ++ & +++ & +++ & $+t$ & +++ \\
\hline & 15 & $1 / 50$ & ++ & ++ & ++ & ++ & ++ & +++ \\
\hline
\end{tabular}

${ }_{1} 0$ : None; $+:$ minimal $(<10 \%) ;++:$ moderate $(10-40 \%) ;+++:$ large $(>40 \%)$. Determined by the proportion of APA removed by specific immunoadsorbtion compared with total serum APA.

2 Prior to use of "complex inactivation method" (see text).

${ }^{3} \mathrm{ND}$ : Not done. 
premature infants, and all classes of immunoglobulin antibodies were represented.

In Table III the proportion of each APA immunoglobulin class in the sera of mother-infant pairs is compared. The proportions were approximately similar in most pairs. However, several pairs were found to have marked discrepancies in the proportion of antibodies of a specific immunoglobulin class.

Table III. Proportion of each immunoglobulin (Ig) class of antipenicillin antibodies in mother/infant pairs $(n=27)^{1}$

\begin{tabular}{lcccc}
\hline \multirow{2}{*}{$\begin{array}{l}\text { Immunoglobulin } \\
\text { class }\end{array}$} & \multicolumn{4}{c}{ Inactivation of penicillin phage $\mathrm{T4} \%$} \\
\cline { 2 - 5 } & $\begin{array}{c}\mathrm{M}:<10 \% \\
\mathrm{I}:>40 \%\end{array}$ & $\begin{array}{c}\mathrm{M}: 10 \%-40 \% \\
\mathrm{I}: 40 \%-10 \%\end{array}$ & $\begin{array}{c}\mathrm{M}:>40 \% \\
\mathrm{I}:<10 \%\end{array}$ & $\begin{array}{c}\text { Insuffici- } \\
\text { ent data }\end{array}$ \\
\hline $\mathrm{IgG}^{2}$ & 1 & 17 & 0 & \\
$\mathrm{IgA}^{2}$ & 0 & 13 & 1 & 1 \\
$\mathrm{IgM}^{2}$ & 4 & 16 & 2 & 59 \\
$\mathrm{IgE}^{2}$ & 3 & 21 & 1 & 23 \\
Heat labile & 2 & 20 & 2 & 35 \\
2-Mercaptoethanol & 6 & 16 & 0 & \\
$\quad$ sensitive & \multicolumn{5}{c}{} \\
\hline
\end{tabular}

M: Mother; I : infant.

$\Delta$ fter immunoadsorption of sera.
Of most interest was the finding of significant differences between sera of mothers and their infants. In three pairs, IgA antibodies were present in the mothers' sera diluted $1 / 500-1 / 1000$, whereas no $\operatorname{IgA}$ antibodies could be detected in their infants' sera at dilutions of $1 / 50-1 / 100$ when other immunoglobulin classes of APA were present. In four pairs, the mother had no IgE APA, whereas the infant did, and, conversely, two mothers had IgE APA while their infants had none (Table IV). No such marked discrepancies were found in the IgG and IgM classes of APA. In two sets of twins (Table V), marked differences were found in each infant pair in the proportions of immunoglobulin class APA. In one set, IgM APA were present in the mother and one infant only, and IgE APA were found in both infants but not in the mother.

\section{Discussion}

It is accepted generally that during intrauterine existence the mammalian fetus is well protected from microbial invasion and other nonmaternal antigenic

Table $\mathrm{XV}$. Immunoglobulin $\mathrm{E}(\mathrm{IgE})$ antipenicillin antibodies in selected mother/infant pairs ${ }^{1}$

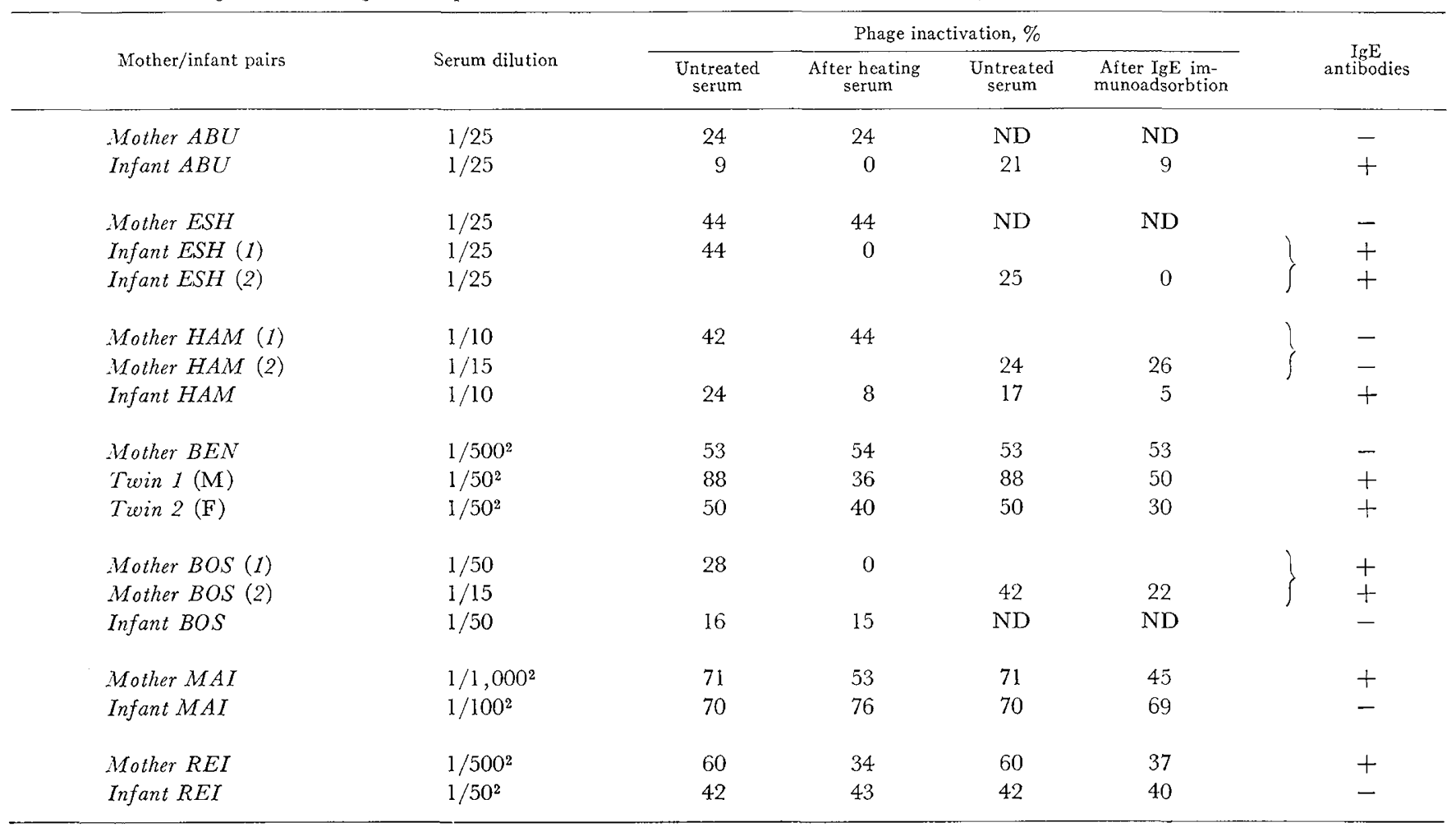

${ }^{1} \mathrm{M}:$ Male; $\mathrm{F}$ : female; ND: not done.

${ }^{2}$ Complex inactivation method (see text). 
Table $V$. Antipenicillin antibodies and their immunoglobulin classes in mothers and their newborn twins ${ }^{1}$

\begin{tabular}{lccrrr}
\hline & Serum dilution & $\operatorname{IgG}$ & $\operatorname{IgA}$ & $\operatorname{IgM}$ & $\operatorname{IgE}$ \\
\hline Mother & $1 / 500$ & 53 & 58 & 49 & 0 \\
Twin 1 (M) & $1 / 50$ & 51 & 5 & 23 & 43 \\
Twin 2 (F) & $1 / 50$ & 16 & 16 & 0 & 40 \\
& & & & & \\
Mother & $1 / 500$ & 88 & 50 & 28 & 15 \\
Twin 1 (M) & $1 / 50$ & 41 & 17 & 57 & 61 \\
Twin 2 (M) & $1 / 50$ & 14 & 15 & 46 & 22 \\
\hline
\end{tabular}

${ }^{1}$ Immunoglobulins $\mathrm{G}, \mathrm{A}, \mathrm{M}, \mathrm{E}: \mathrm{IgG}, \operatorname{Ig} \mathrm{A}, \operatorname{IgM}, \operatorname{IgE} ; \mathrm{M}:$ male; $\mathrm{F}$ : female. The proportion of total serum antipenicillin antibodies removed by specific immunoadsorption is expressed as a percentage of penicillin phage $\mathrm{T} 4$ inactivation (e.g., if total APA gives $80 \%$ inactivation, and after IgG immunoadsorption gives $40 \%$, then the proportion of IgG APA is $50 \%$ ).

stimulation. For this reason fetal immunoglobulin production is minimal and only postnatally are significant amounts of immunoglobulins synthesized which may be detected by accepted laboratory techniques. Until birth, passive antibodies pass the placenta from mother to fetus, and provide the unborn infant with a protective humoral immune system. As early as the 4th month of gestational age, maternal IgG has been found in fetuses. The kinetics of transport and other factors suggest strongly that the passage of $\operatorname{IgG}$ molecules across the placenta is not a passive process, but determined by a placental transport site present on the $\gamma$ chain. Larger and larger amounts pour across this placental barrier until, at term, the infant is born with equal, if not greater, quantities of IgG than his mother [13]. The concentration of IgG subclasses too has been measured in matched pairs of maternal and cord serum by single radial immunodiffusion. $\operatorname{Ig}_{1} \operatorname{IgG}_{3}$, and $\mathrm{IgG}_{4}$ were present in similar amounts in both mothers and infants. $\operatorname{IgG}_{2}$, however, was present in mothers at about three times the amount found in cord serum [10]. The IgG antibody can be identified as maternal by its antigenic structure and its specificities, and can be differentiated from fetal IgG which may have paternal allotype markers present. This passage is a two-way process, as fetal IgG has been found in the mother [6].

It has been assumed that $\operatorname{Ig} M, \operatorname{IgA}, \operatorname{IgE}$, and $\operatorname{Ig} \mathrm{D}$ do not pass the placental barrier, but newer techniques have shown that possibly small amounts of these immunoglobulins, especially IgA, can get across from mother to infant and vice versa [6], but they are present at much lower levels in the neonate [13].

Our results indicate that antibodies which specifically inhibit growth of bacteriophage T4 coupled to penicillin were present in the sera of all mothers and their newborn infants. In general the optimum serum dilution for detecting these antibodies was in the order of 5-10 times higher in the mother than in her infant, which indicated the presence of either greater amounts or more efficient antibody in the mother than in the child. These antibodies are of four immunoglobulin classes, $\operatorname{IgG}, \operatorname{IgM}, \operatorname{IgA}$, and $\operatorname{IgE}$, but not $\operatorname{IgD}$, and in the majority of paired sera, the proportion of each APA class was approximately the same. However, a significant discrepancy in the proportion of antibody classes was found in up to $20 \%$ of pairs in which the infant had higher proportions (excluding IgA), and in up to $27 \%$ of pairs in which the mother had higher proportions. These marked discrepancies in themselves are not sufficient evidence to indicate that antibodies in each immunoglobulin class are being actively produced independently in the fetus and mother, but they are highly suggestive. Some, if not all, of this antibody may be passed selectively through the placenta from the mother to her infant, and in the absence of markers in this study, it becomes impossible to differentiate between active and passive antibody in the fetus. The finding, however, in several mother-infant pairs, of a specific immunoglobulin antibody in one of the pair only, allows more definitive conclusions to be drawn. In several cases IgE antibodies were found in the neonate, but not in the mother, which indicates that the fetus can actively synthesize IgE. Again, the finding of $\operatorname{IgE}$ antibodies in the mother and not in the fetus indicates that this antibody has not passed the placenta, there being no evidence that IgE antibody which may pass the placenta is destroyed or removed immediately from the infant's circulation.

The same reasoning applies to IgA antibodies, as in several pairs the IgA APA were found only in the mother, and did not pass through the placenta to the infant. As it seems most unlikely that each individual mother-fetus pair has different factors involved which determine whether the IgA antibody will pass to the child, the probability is that IgA antibodies are independently produced in mother and fetus.

In this limited study, no mother-infant pair was found in which IgM or IgG antibodies were absent in one of the pair, but the marked discrepancies in the proportion of these immunoglobulin classes in some mothers and their newborn infants is highly suggestive that in these two immunoglobulin classes as well, there is independent synthesis of APA by the fetus.

The finding of four immunoglobin classes of APA (excluding $\operatorname{IgD}$ ) in premature infants indicates that 
the fetus is capable of synthesizing all of these classes of immunoglobulin as early as 6 months of gestational age.

The requirement for antibody production by the fetus is antigenic stimulation, but this stimulation does not reach its peak until birth when the fetus breaks out of its protected environment. At this time active antibody synthesis to a variety of antigens can be demonstrated. However, there is now ample evidence that the human fetus has an immune mechanism which starts to develop as early as the 3rd or 4th month of gestational age and which is competent to respond to antigenic stimulation.

Lymphoid cells may be identified in the mesenteric lymph nodes at approximately 8 weeks gestational age. By 9 weeks they begin to appear in the thymus and a week later in the peripheral blood [6]. Plasma cells may also be found in the fetus, usually after intrauterine infections such as with syphilis or toxoplasmosis [18]. Van Furth et al. [23] showed in 1965 that IgM and $\mathrm{IgG}$ could be demonstrated regularly in lymphoid cells of the human spleen from the 20th week of gestational age, and a little later in lymphoid cells outside of the spleen. Gitlin [6] more recently demonstrated synthesis of minute amounts of $\operatorname{IgM}$ in embryonic spleen at 10.5 weeks gestational age, and $\operatorname{IgG}$ at 12 weeks. IgM antibodies appear early after infection of the fetus and its presence in cord sera in quantities above $10 \mathrm{mg} / 100 \mathrm{ml}$ has been used as an indication for prenatal infection. However, even in the absence of evidence of infection, IgiM can be regularly found in cord sera of premature infants, and within 3-4 days of immunization of 23-26-week-old premature infants at birth.

$\operatorname{Ig} G$ synthesis by the fetus has also been proved by the presence of paternal $\mathrm{Gm}$ allotypes in the fetal immunoglobulins. This fetal IgG was present in sufficient quantities at 7 months gestational age, in order to pass back through the placenta to a $\mathrm{Gm}(\mathrm{a})$ - mother and sensitize her to fetal Gm(a) + IgG [5].

Minute amounts of IgA may be found in the serum of 6-10-week-old fetuses, but there has been very little evidence so far for significant IgA production by the fetus even as late as the 31 st week [1]. At birth IgA is absent from most cord sera, or is present in very low concentration when measured by standard techniques. However, IgA as well as secretory piece "T" of IgA, have been repeatedly demonstrated in saliva of neonates [19]. In neonates with congenital viral infections, IgA can be found regularly in cord serum. It has also been known that small amounts of IgA may pass through the placenta to the fetus and vice versa, leading to the formation of anti-IgA immunoglobulins either in the mother or the fetus [6].

$\operatorname{IgD}$ globulins, the antibody status of which is not yet clear, have not been detected in cord sera, and their synthesis starts sometime after birth [15]. None of the seven mothers or five neonates whom we tested had evidence of $\operatorname{IgD}$ APA.

Recently it has been shown that $\operatorname{IgE}$ is present in relatively small amounts in most cord sera [2]. As there was no relation to IgE levels in the mother, it was suggested that $\mathrm{IgE}$ does not pass the placental barrier. Also, the ability of $\operatorname{IgE}$ to fix to dermal cells and give positive skin reactions with anti-IgE develops only a few weeks after birth [21], which indicates that the $\operatorname{IgE}$ of the infants differs biologically from that of the mothers, and is, therefore, probably not passively obtained from the mother.

Our own results suggest that the fetus can actively produce $\operatorname{IgG}, \operatorname{IgM}, \operatorname{IgA}$, and $\operatorname{IgE}$ antibodies as early as 6-7 months of gestational age, and that $\operatorname{IgE}$ and IgA probably do not pass regularly through the placenta. Animal studies have shown also that, once the fetus is able to respond to a given antigen, its response appears to be adult-like with respect to both heterogeneity of immunoglobulin product and the appearance of both humoral and cellular immune components [17].

Active immunoglobulin production by the fetus indicates that antigens are crossing the placenta; this begins probably in the 4 th month of pregnancy if not earlier. It is known that viruses such as rubella may enter the fetus during the first trimester of pregnancy, which leads to congenital malformation of the embryo. At exactly what stage these viruses stimulate antibody formation is not clear, but at birth, premature or full term, the amount of specific antibody of IgM class present, and presumably actively produced, can be measured in milligrams $/ 100 \mathrm{ml}$. Known sources [22] of intrauterine antigenic stimulation include $(1)$ other prenatal infections of mother and fetus by viruses, bacteria (syphilis), and parasites (toxoplasmosis); (2) isoantigens coming from the mother such as Gm, haptoglobin, $\lambda$ light chain and other allotypes; and (3) maternal histocompatibility antigens from the leukocytes which are known to pass through the placenta into the fetal circulation.

The probability that a host of other unknown antigens such as penicillin or penicillin-like substances pass from mother to fetus, leading to prenatal antigenic stimulation, is suggested by our present study. The possibility that the placenta itself is immunologi- 
cally competent, therefore accounting for some of the antibody found in the fetus, is not supported by any conclusive evidence [3].

The finding in this study of the universality of APA is somewhat surprising. Penicillins are known to produce immunologic manifestations either due to high molecular weight impurities in the commercial preparations of penicillins, or to the reaction of penicillins or their degradation products with autologous proteins, thereby becoming immunogenic and antigenic [16]. The presence of APA per se does not indicate an allergic state, and clinical manifestations of allergy are not usually present despite the fact that the majority of individuals do have APA. What the determinants are for the development of the allergic state are not known for certain, although studies have shown that $\mathrm{IgE}$ antibodies may be important in the determination of penicillin hypersensitivity by themselves, or when they are in an increased ratio to IgG APA, which possibly act as blocking antibodies [24]. All of the mothers and their newborn infants tested by the modified phage inactivation technique for detecting APA, which is known to be able to detect as little as $0.2 \mathrm{ng}$ antibody/ml [9], were positive, although none was known to have any form of allergy to penicillin. However, a recent study using passive hemagglutination of human group $O$ erythrocytes coupled to the benzylpenicilloyl hapten group, failed to demonstrate APA in $90 \%$ of neonatal cord blood [4]. These same authors indicate that their studies showed that there was de novo synthesis of IgM penicilloyl-specific antibodies in the fetus.

Our own studies show that four immunoglobulin classes (IgG, IgM, IgA, and IgE) of APA may be present in the newborn infant (Table III). One can speculate that the source of the penicillin antigen is in the food and milk which we drink, and which is known to contain antibiotic and other "pollutants." However, the possibility must be borne in mind that these APA are either of low affinity or are cross-reacting antibodies not specifically induced by penicillin, but due to exposure to unknown compounds which resemble penicillin in structure. This could explain the necessity in some experiments for the relatively high concentrations of penicillin needed to inhibit the reaction between the modified phage and the antisera. This possibility must be borne in mind considering the fact that in parallel studies we have shown that all newborn infants have antibodies of various immunoglobulin classes with specificity directed towards the dinitrophenyl hapten [12]. Another possibility to be consid- ered is that a relatively high proportion of antibodies of different specificities is capable of cross-reacting with penicillin.

\section{Summary}

Studies of matched sera from mothers and their newborn infants indicate that the fetus is competent to produce $\operatorname{IgG}, \operatorname{IgM}, \operatorname{Ig} \mathrm{A}$, and $\operatorname{IgE}$ immunoglobulins. With the use of the highly sensitive technique of antibody inactivation of chemically modified bacteriophage, we found that all 25 mothers tested, and their 27 newborn infants, have APA in their sera. These antibodies are of four immunoglobulin classes (excluding $\operatorname{Ig} \mathrm{D})$, and in general, mothers have from $5-10$ times more or more efficient antibodies than their infants. Premature infants of 6-7 months were also shown to have these antibodies. Although in the majority of mother-infant pairs there was a positive correlation in the proportion of each immunoglobulin class of APA, sufficient pairs were found in which there was a marked discrepancy in these proportions. This is suggestive evidence that some, if not all of the IgM, $\operatorname{IgA}$, and $\operatorname{IgE} \mathrm{APA}$, and a portion of the IgG antibodies are produced independently by the mother and her infant. Several pairs studied in which IgE APA were found in the infant but not in the mother, prove that the fetus is able to synthesize $\operatorname{IgE}$. Other pairs in whom the mother had $\operatorname{IgE}$ antibodies, but not her infant, suggest that $\mathrm{IgE}$ does not pass regularly through the placenta. The finding of IgA antibodies to penicillin in the sera of some mothers, but not in their newborn infants, suggests that these IgA antibodies do not pass the placenta, and therefore any IgA antibodies in fetal sera are actively produced.

As it is known that neither mothers nor infants had received penicillin during pregnancy, it is suggested as a possible explanation that penicillin or penicillin-like antigens are ingested by the mother, possibly as pollutants in food and milk, and these pass through the placenta to the fetus and stimulate the humoral immune mechanism. These studies are further evidence of the competence of the fetal immune mechanism.

References and Notes

1. Adams, M. H.: Bacteriophages, p. 450. (Interscience, New York, 1959),

2. BazAral, M., Orgel, H. A., and Hamburger, R. N.: IgE levels in normal infants and mothers and an inheritance hypothesis. J. Immunol., 107: 794 (1971).

3. Billincton, W. D.: Immunological processes in mammalian reproduction in immunology and development. In: M. Adi- 
nolfi and J. Humphrey: Clinics in Developmental Medicine, No. 34, p. 104. (Heinemann Medical Books, Ltd., London, 1969).

4. Feltner, M. J., Klaus, M. V., Baer, R. L., and Rausen, A. R.: Antibody production in normal children receiving penicillin at birth. J. Immunol., 107: 1440 (1971).

5. Fudenberg, H. H., Stiehm, E. R., Franklin, E. C., Meltzer, M., ANd Frangrone, B.: Antigenicity of hereditary human gamma globulin $(\mathrm{Gm})$ factors: Biological and biochemical aspects. Cold Spring Harbor Symp. Quant. Biol., 29: 463 (1964).

6. Grtuin, D.: Development and metabolism of immune globulins. In: B. M. Kagan and E. R. Stiehm: Immunologic Incompetence. (Year Book Medical Publishers, Chicago, 1971).

7. Grvol, D., AND Rotman, M.: Insoluble antibody columns. Israel J. Med. Sci., 6: 452 (1970).

8. Haimovich, J., Hurwitz, E., Novik, N., and Sela, M.: Preparation of protein bacteriophage conjugates and their use in the detection of anti-protein antibodies. Biochim. Biophys. Acta, 207: 115 (1970).

9. Haimovich, J., Sela, M., Dewdney, J. M., and Batchelor, F. R.: Antipenicilloyl antibodies: Detection with pencilloylated bacteriophage and isolation with a specific immunoadsorbent. Nature, 214: 1369 (1967).

10. Hay, F. C., Hull, M. G. R., and Torrigiani, G.: The transfer of human IgG subclasses from mother to foetus. Clin. Exp. Immunol., 9: 355 (1971).

11. Levin, S., Altman, Y., and Sela, M.: Penicillin IgE antibodies in newborns and mothers, detected by chemically modified bacteriophage. Israel. J. Med. Sci., 6: 742 (1970).

12. Levin, S., Altman, Y., and Sela, M.: Penicillin and dinitrophenyl antibodies in newborns and mothers detected with chemically modified bacteriophage. Pediat. Res., 5: 83 (1971).

13. Oudin, J., And Stoltz, F.: Les concentrations des antigenes du serum humain dans des ètats physiologiques ou pathologiques differents. Ann. Inst. Pasteur, 121: 581 (1971).

14. Porath, J., Axen, R., And Ernback, S.: Chemical coupling of protcins to agarose. Nature, 215: 1491 (1967).

15. Rowe, D. S., Crabbé, P. A., and Turner, M. W.: Immunoglobulin $\mathrm{D}$ in serum, body fluids and lymphoid tissues. Clin. Exp. Immunol., 3: 477 (1968).
16. Shaltiel, S., Mizraceit, R., and Sela, M.: On the immunological properties of penicillins. Proc. Roy. Soc. Ser. B Biol. Sci., 179: 411 (1971).

17. Silverstern, A. M.: Immunologic maturation in the fetus. Modulation of the pathogenesis of congenital infectious discase. In: Ontogenesis of Acquired Immunity. (Ciba Foundation, Churchill, London (in press)).

18. Silverstern, A. M., And Lukes, R. J.: Fetal response to antigenic stimulus. I. Plasmacellular and lymphoid reactions in the human fetus to intrauterine infection. Lab. Invest., 11: 918 (1962).

19. South, M. A., Cooper, M. D., Hong, R., And Good, R. A.: The IgA antibody systems. In: A. A. Moscona and A. Monroy: Current Topics in Developmental Biology, Vol. 2, p. 191. (Academic Press, New York, 1967).

20. Stanworth, D. R.: Immunoglobulin E (reagin) and allergy. Nature, 233: 310 (1971).

21. Stevenson, D. D., Orgel, H. A., Hamburger, R. N., ANd Ried, R. T.: Development of $\mathrm{IgE}$ in newborn human infants. J. Allerg. Clin. Immunol., 48:61 (1971).

22. Thoribecke, G. J., AND VAN Furth, R.: Ontogeny of immunoglobulin synthesis in various mammalian species. $I n: \mathrm{R}$. T. Smith, R. A. Good, and P. A. Miescher: Ontogeny of Immunity, p. 173. (University of Florida Press, Gainesville, Fla., 1967).

23. Van Furth, R., Schurt, H. R. E., and Hijarans, W.: The Immunological development of the human fetus. J. Exp. Med., 122: $1173(1965)$.

24. Wheeler, A. W.: A method for measuring different classes of human immunoglobulins spccific for the penicilloyl group. Immunology, 21: 547 (1971).

25. National Institutes of Health, Bethesda, Md.

26. The technical assistance of Thalia Hahn and Edna Sakal is gratefully appreciated.

27. This research was supported by a grant from the Joint Research Fund of the Hebrew University and Hadassah, Jerusalcm, Isracl.

28. Requests for reprints should be addressed to: STANLEY Levin, M.D., Kaplan Hospital, Rehovot, Israel.

29. Accepted for publication March 5, 1973. 